\title{
Students and the Teacher's Perceptions on Incorporating the Blog Task and Peer Feedback into EFL Writing Classes Through Blogs
}

\author{
Hsin-Yi Cyndi Huang ${ }^{1}$ \\ ${ }^{1}$ Department of Applied English, Southern Taiwan University of Science and Technology, Tainan, Taiwan \\ Correspondence: Hsin-Yi Cyndi Huang, Department of Applied English, Southern Taiwan University of Science \\ and Technology, No.1 Nan-Tai Street, Yungkang Dist., Tainan City 710, Taiwan. Tel: 886-6-2533131 ext. 6101. \\ E-mail: cyndihuang@stust.edu.tw
}

\author{
Received: August 8, 2016 Accepted: October 8, 2016 Online Published: October 11, 2016 \\ doi: 10.5539/elt.v9n11p38 URL: http://dx.doi.org/10.5539/elt.v9n11p38
}

\begin{abstract}
With the availability of Web 2.0 technologies, blogs have become useful and attractive tools for teachers of English as a Foreign Language (EFL) in their writing classes. Learners do not need to understand HTML in order to construct blogs, and the appearance and content can be facilitated via the use of photos, music, and video files (Vurdien, 2013). To provide an authentic and motivating writing environment, a blog task was designed and integrated into three writing courses for 57 applied English or English major students at two southern Taiwan universities. Using the triangulated approach, this study collected data from three different angles (students' questionnaires, students' focus group interviews, and the teacher's observation log) to investigate whether participant perceptions empirically supported the theoretical hypothesis that blogging contributes to writing performance. The findings showed that both the teacher and students had a positive attitude towards the blog task and may indicate that blogging is a useful alternative approach but may also be regular incorporated in writing classes to enhance EFL writing motivation. Nevertheless, blogs may not be the most suitable tool for all types of writing tasks and the most appropriate medium for all components of feedback. The conclusions of this study are consistent with previous findings on the practicality and potential of using blog software to promote peer feedback as well as to facilitate effective writing instruction.
\end{abstract}

Keywords: blogs, peer feedback, perceptions, EFL writing

\section{Introduction}

Writing skills are crucial for students in higher education and their future careers. However, they are not easily acquired and students need special training for writing in a foreign language. Therefore, many college students within English or applied English majors struggle in English composition classes and consider it the most difficult skill to acquire, for three reasons. First, they are not used to thinking in English and tend to use direct translations from the mother tongue to English. Second, they may not have strong English grammatical knowledge. Third, they may have lower motivation for writing tasks and assignments in traditional writing classes, since the writing teacher is usually the only perceived audience for the students' writing (Aljumah, 2012; Davis, 1997). Therefore, practitioners are finding ways to create more authentic and motivating writing environments for EFL writers. At present, the use of computer mediated communication (CMC) technologies, such as blog platforms, is free and available. Hence, incorporating blog tasks into writing courses may boost EFL students' writing motivation and effectiveness because they are aware that both the teacher and their peers, and perhaps the world, are reading their writing (Aljumah, 2012).

Blogs have emerged as a new genre of writing since the late 1990s. Writers post their daily lives or write about a particular field or topic. However, unlike social networks such as Facebook, blogs focus more on presenting oneself in writing. In recent years, blogs have been applied in foreign language teaching because they provide learner writers with an authentic language environment to reach wider audiences, and allow the teacher and student peers to offer feedback and to promote negotiation for meaning.

This paper begins with a review of the literature on blogs as a tool for teaching writing and for promoting student writing ability and peer feedback. It then describes how the blog task was incorporated into the writing classes. Using a triangulated approach, data from student questionnaires, interviews, and researcher's observations are presented. This paper concludes with a discussion of the pedagogical implications of blogs in teaching EFL 
writing.

\section{Literature Review}

\subsection{Blogs as an Interactive, Motivating and Authentic Platform for Teaching and Learning Writing}

Blogs, like other online communications technologies, have become a platform for foreign language teaching (Arnold \& Ducate, 2006; Richardson, 2005; Yang, 2009). With their interactive nature, blogs have been investigated in several studies as a motivating and effective tool for developing writing skills in the target language (Arslan \& Sahin-Kizil, 2010; Dippold, 2009; Vurdien, 2013). Through incorporating blog tasks in writing classes, students can choose their topics of interest and produce their writing in creative, reflective and personal ways. They can also comment on their peers' blogs and receive feedback from their peers. By responding to their peers' comments or commenting on their peers' blogs, students can practice both reading and writing skills. Hence, blogs not only facilitate the exchange of ideas and self-reflection, but also enable students to provide feedback on their peers' work, which create a more relaxed, student-centered, and self-paced reading and writing target language environment (Aljmah, 2012; Godwin-Jones, 2008; Vurdien, 2013; Ward, 2004; Williams \& Jacobs, 2004). For pedagogical purposes, the effective use of blogs extends the classroom and enables learners to share knowledge. This further facilitates student-centered learning and enhances individual accountability in self-regulated learning (Du \& Wagner, 2007 as cited in Sun \& Chang, 2012). Additionally, Ward (2004) mentions that blogs offer learners an authentic environment to communicate with each other through writing. By the means of blogs, learner authors learn to present themselves, exchange information, and build their social networks (Sun, 2009). Therefore, the use of blogs may increase authenticity in both learning and teaching of English writing.

\subsection{Peer Feedback in Writing Classes}

Traditionally, in writing classes, teachers' feedback is usually the only source of feedback that students can rely on. However, from a sociolinguistic perspective, social interaction can result in meaningful learning and individual development (Wu, Petit, \& Chen, 2015). Rollison (2005) noted that peer feedback, regarded as a form of social interaction, may foster EFL writing motivation and produce positive learning outcomes. Vygotsky (1978) emphasized the vital role of social interaction and noted that the assistance from a more knowledgeable person, also known as scaffolding, can promote one's learning. Therefore, blogging can serve as a tool and a natural way for promoting social interaction through leaving comments, a form of computer-mediated communication (CMC) feedback. Different from traditional face-to-face peer feedback, peer feedback on blogs is an asynchronous CMC mode. According to Chang (2012), online CMC modes may be a less pressured venue for students to make critical comments since they are not face-to-face. Chang further noted that in CMC modes, reviews are allowed to have extended response time and they can provide comments and edit writing mistakes at convenient time and at their own pace. Moreover, Nicol and MacFarlane-Dick (2006) observed that peer feedback is not merely helpful for the persons who receive it but also beneficial to those who provide it since students need to read critically when they are engaged in the peer review process. If they can help their peers edit their drafts, it means they also possess the ability to edit their own writing. In order to provide feedback, students practice certain skills, such as asking questions, replying to inquiries, and fostering productive interactions (Baggetun \& Wasson, 2006 as cited in Dippold, 2009).

Regardless of the benefits of peer feedback, many EFL writing teachers do not use it because they believe peer feedback is time-consuming and ineffective. This is because (1) pre-training consumes a great deal amount of time and (2) teachers need to take time to persuade students about the value of peer feedback (Rollinson, 2005). Moreover, most EFL students believe that both themselves and their peers lack the expertise to provide quality feedback and should not have that authority (Hanrahan \& Isaacs, 2001; Liu \& Carless, 2006). Therefore, Min (2006) stated that to gain quality and effective peer feedback, training is necessary before students give feedback to their peers. Research on peer feedback has identified its strengths and weaknesses. However, more voices from EFL students and teachers from studies of actual writing classrooms should be heard and reported. That is one of the major contributions of this study.

\section{Research Methods}

\subsection{The Setting and Participants}

This study project was implemented in three writing classes at two universities located in Sothern Taiwan. Among the three writing classes, two classes (referred as class 1 \& 2) are from the Advanced English Writing course consisting of 41 college Applied English majors from Chia Nan University of Pharmacy \& Science (21 students in class 1 and 20 students in class 2). The other class (referred as class 3 ) is the Composition IV course 
comprising 16 night-school sophomores studying in the English Department at National Tainan University. The English proficiency of the students in three classes varies, but most were high beginners, some low intermediates, and a few intermediates.

\subsection{Blog Instruction}

At the beginning of the semester, students were told that in addition to regular writing assignments, a blog task was incorporated into the syllabus. In three designated weeks (week 9, 14, 15) after the midterm, students went to a computer lab for the blog task. In week 9 , the instructor first showed several sample blogs she had created, and then guided the learners in setting up their own blogs on Blogger.com by viewing tutorials on YouTube. These tutorials present step-by-step guides to the students, from creating an account and naming the blog, to choosing a template for it. After a simple blog is created, students can begin adding a post. Students can freely access peer blogs and leave comments on posts. Further, the owners of the blog can view the comments and respond to them, which creates an interactive mode of communication. Once the learners had learned how to create their own blogs, they were instructed to post an entry of around 150 to 200 words based on the topic they chose related to their interests or daily life, which they thought worth sharing. In Week 14, the instructor had students complete their first blog posting during the first period of the class time. When finished, students had to paste their blog addresses on the class' discussion board of the school's e-learning platform so that everyone in the class can access their blogs. During the second hour of class time, the students were asked to read all the class' blog postings and to leave a comment on the assigned partner's posting. The teacher used the peer review guide questions (see Appendix A) to instruct the students on how to leave a comment for their peers. Students were asked to write about their reactions after reading their peers' postings, review the clarity of the content, and identify grammatical or spelling errors they found in the text. In Week 15, the instructor had the students read the comments left on their postings by the teacher and the students and respond to them. In addition, the students were asked to revise the content of their postings again for clarity and grammatical accuracy based on the comments from the teacher and their peers.

\subsection{Research Questions, Instrument, and Data Collection}

This study examines the learners and the teacher's perceptions of the blog task and addresses the following questions:

(1) What are the EFL students and the teacher's perceptions of the use of blog in writing classes?

(2) What are the EFL students and teacher's perceptions of the advantages and disadvantages of using blogs in writing classes?

(3) How effective and helpful do students think peer feedback is to their writing?

A survey questionnaire with 16 items (see Appendix B) was designed for investigating student perceptions of the blog task. The sixteen items serve to elicit the participant perceptions of five aspects: learning motivation and attitude (items 1 to 3), reading and writing skills (item 4 to 7), benefits of peer feedback (item 8 to 11), the comparison between peer feedback and teacher feedback, (item 12 to 13), and the extra benefits of using blogs (item 14 to 16). The questionnaire was also piloted by two graduate students to check the validity and reliability of each item. Then, then items were further modified and improved based on the two students' feedback in the pilot test and their suitability for Taiwanese students learning English. To avoid miscommunication and increase comprehension, the questionnaire was first written in Chinese and further translated into English for research purposes. The questionnaire was administered in the last class of the semester and the learners responded to the statements using a five-point Likert scale in which $5=$ strongly agree and $1=$ strongly disagree. The reliability of each item was tested using Cronbach's alpha. The Cronbach's alpha from item 1 to item 16 is .926 , which implies the questionnaire reached a high reliability.

The study used a triangulation approach in order to capture different perspectives as shown in Figure 1 (Dippold, 2009). The first part of the data was gathered via the abovementioned questionnaire, which was administered to the students in Week 18 (the final week of the semester) to learn about their perceptions of the blog task. The second part of the data, students' focus group interviews, were also collected in Week 18 during the second class period. In each class, students were divided into 4 groups, around 4 to 5 students in a group. They were asked to comment on the advantages and disadvantages of incorporating blogs into writing classes. The final part of the data was drawn from the class instructor's observation notes of student engagement while doing the blog task in class and the instructor's perceptions after reading and giving comments on each student's blog posts. The three strands of data were analyzed by qualitative coding to look for patterns, themes, and categories and by Excel calculation for quantitative results. The results of the three strands were then compared and analyzed together to 
obtain a clearer picture of the implementation of the blog task, which is discussed below.

\section{Instructor/Researcher:}

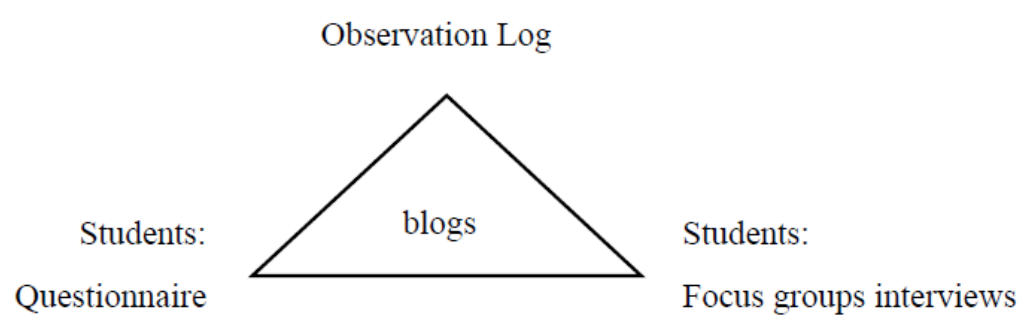

Figure 1. Triangulated research methods

\section{Results}

\subsection{The Questionnaire}

Table 1 presents the mean scores of each class and the mean scores of the three classes on the sixteen items in the questionnaire. Item 3, which asked participants if they felt writing blog assignments was easier and more motivating because the blog assignment did not have defined topics and they had more freedom to choose what they wanted to write about, had the highest mean score. Item 14, which asked the participants if they thought using blogs in writing classes was more efficient and green because both the teacher and classmates could comment on each other's blogs, which saved time and reduced paper waste as opposed to the traditional writing classes, was second highest. Item 15, in which the participants were asked if they thought incorporating blogs into a writing course provided authentic material and was a way to integrate language learning with real-life activities, which was very meaningful, had the third highest score. Item 6 , which asked the participants if they felt the writing assignment in the blog task could be helpful in practicing the English words they have learned had the lowest mean score. Item 5, which they were asked whether they thought completing blog assignments could be helpful in promoting their writing skills, had second lowest score. The third lowest score was item 9, which asked whether participants thought the classmate's comments on their blogs were helpful to them in correcting the grammatical and spelling mistakes in their own blog posts.

Table 1. Summary of mean scores of the questionnaire

\begin{tabular}{lllllllll}
\hline & Item 1 & Item 2 & Item 3 & Item 4 & Item 5 & Item 6 & Item 7 & Item 8 \\
\hline Class 1 Mean & 4.29 & 4.29 & 4.76 & 4.05 & 3.67 & 3.76 & 4.00 & 4.29 \\
Class 2 Mean & 4.35 & 4.10 & 4.40 & 4.15 & 3.80 & 4.00 & 3.95 & 4.35 \\
Class 3 Mean & 4.38 & 4.13 & 4.69 & 4.31 & 4.38 & 4.00 & 4.25 & 4.38 \\
Class1+Class2+Class 3 Mean & 4.34 & 4.17 & 4.62 & 4.17 & 3.95 & 3.92 & 4.07 & 4.34 \\
& Item 9 & Item 10 & Item 11 & Item 12 & Item 13 & Item 14 & Item 15 & Item 16 \\
Class 1 Mean & 3.90 & 4.14 & 4.29 & 4.38 & 4.33 & 4.43 & 4.33 & 4.10 \\
Class 2 Mean & 4.05 & 4.05 & 4.30 & 4.40 & 4.40 & 4.60 & 4.50 & 4.35 \\
Class 3 Mean & 4.06 & 4.06 & 4.31 & 4.50 & 4.63 & 4.63 & 4.75 & 4.50 \\
Class1+Class2+Class 3 Mean & 4.00 & 4.08 & 4.30 & 4.43 & 4.45 & 4.55 & 4.53 & 4.32 \\
\hline
\end{tabular}

\subsection{The Focus Group Interviews}

In the focus group interviews, the participants were interviewed about their opinions of advantages and disadvantages of incorporating blog tasks into writing classes. The reoccurred themes from students' answers were synthesized into various categories. Table 2 presents the percentages and rankings of each category of the advantages of incorporating blog tasks into writing class. 
Table 2. Advantages of incorporating the blog task into writing classes

\begin{tabular}{lll}
\hline Advantages & Percentage & Ranking \\
\hline Free from being bounded and limited by the topics & $49.1 \%$ & 1 \\
Learning from and interacting with peers & $40.4 \%$ & 2 \\
More fun, interesting, innovative, interactive and motivating & $31.6 \%$ & 3 \\
Authentic and related to lives & $17.5 \%$ & 4 \\
Improving language ability and writing fluency & $14.0 \%$ & 5 \\
Convenient, green, and looking up unknown words online immediately & $10.5 \%$ & 6 \\
\hline
\end{tabular}

For the advantages of incorporating blogs, about $49.1 \%$ of the participants mentioned that blogging was easier to write and master, and they enjoy doing it since they choose the topics themselves, which fits their own learning styles. The second highest ranking advantage (40.4\%) was learning from and interacting with peers on blogs. The participants thought that blogs made them able to learn from peers when they read the peers' articles and interacted with them. They learn from their peers' writing skills by observing how they write the beginning, body, and conclusion. They also added that blogs help them to get to know their classmates better through interacting with them. In addition, they said that editing each other's writing online improves their reading and writing skills. They also said that peer feedback helps both their classmates and themselves. Around $31.6 \%$ of them said that compared with traditional pen-and-paper writing, blogging, enriched with added photos, pictures, and background music, was more interesting, attractive, and less dull. Therefore, it was easier to arouse and promote student interest in writing. The students also mentioned that blogs were fun, fresh, innovative, different, lively, interactive, motivating, and a great way to learn. Authenticity $(17.5 \%)$ was fourth. Student writing content is usually related to their lives. They noted that being able to incorporate writing into real life was practical and could increase student interest and writing motivation. The students ranked improving language ability and writing fluency fifth. A number of participants mentioned that by practicing grammar and words they have learned, blogging promoted their thinking and improved their grammar, expressions, and writing fluency. Further, multiple exposures to the new words increased their opportunity to memorize new words and to think and write in English. The lowest ranking advantage was green, since writing blogs needed no paper. In addition, the students stated that they could look up any unknown words and their usage online immediately, which helped them learn new vocabulary. Some other advantages mentioned by the participants include they could share their own life, joy, and mood with classmates via blogs, and that blogging was less pressured. Moreover, receiving comments from both the teacher and the classmates made them feel that their writing was worthwhile and meaningful, which encouraged and pushed them to write better.

Fewer participants mentioned disadvantages of blogging in the interviews (see Table 3). First, ten out of 57 participants, roughly $17.5 \%$, said that blogging is more like writing a diary and it is hard to keep doing it. It is less formal and is different from academic writing so it offers little training in practicing organization of essay types. Second, five out of 57 participants mentioned that only incorporating one blog task into the course cannot make a big difference and they suggested that the teacher incorporate more blog assignments into the writing course so that students can apply English in their daily lives more frequently. Third, four out of 57 participants talked about the benefits of traditional writing and the risks of violating privacy, respectively. Four of them pointed out that writing with a pen is more real and tangible. Four also said that some people might not want all their classmates to read their writing but Blogger cannot control who can see the blog, which might be a privacy concern. Three participants said that it was easier to write an assigned topic because sometimes they could not choose what to write. Finally, two participants said that blogs cannot be done without computers, the Internet, and computer skills. Two mentioned that they were worried about the correctness of their grammar and new words in their blog writing and had to wait for the comments that people leave on their blogs. The other two were concerned that students may easily become distracted by the computer in front of them and will not concentrate on the teacher or the assignment when they are in the computer lab. 
Table 3. Disadvantages of incorporating the blog task into writing classes

\begin{tabular}{lll}
\hline Advantages & Percentage & Ranking \\
\hline Diary kind and lack of organization training & $17.5 \%$ & 1 \\
Only one blog task assignment incorporated & $8.8 \%$ & 2 \\
Writing with pen is more real and tangible & $7.0 \%$ & 3 \\
Risk of violating privacy & $7.0 \%$ & 3 \\
It's easier to write with an assigned topic & $5.2 \%$ & 5 \\
Can't be done with computers and the Internet & $3.5 \%$ & 6 \\
Lack of feedbacks and corrections & $3.5 \%$ & 6 \\
Distraction & $3.5 \%$ & 6 \\
\hline
\end{tabular}

\subsection{The Observation Log}

Reading students' blog assignments was profoundly enjoyable and interesting for me as the writing instructor as well as the researcher due to the interactive nature of the blogosphere. Grading students' writing assignments was no longer a tiring and tedious job. Rather, I was motivated since I had also learned from the information students shared on their blogs. In addition, I could examine and comment on the students' writing anytime I had internet access. In the past, the researcher had asked a writing class of applied English majors to do peer reviews face-to-face in the pen-and-paper mode, and many unexpected situations occurred. For instance, some students forgot to bring their drafts to the class, while others could not produce any feedback for their peers. Still others couldn't finish writing their feedback in one class period. The aforementioned conditions had left me with some doubts about using peer feedback in writing classes. However, in the blog task, the participants were more capable of providing feedback via the asynchronous online blog mode. Because of the authentic, real-life, and personal experience of their peers' blog posting, which were less formal than academic writing, participants did not feel they were unqualified to judge or comment on their peers' written work. All the participants could successfully leave useful comments.

Nevertheless, in the beginning of using blogs to give comments on students' drafts, I felt the blog interface was more difficult for the writing teacher to signpost students' language errors than marking directly on students' writing papers. On Blogger, I could only copy the students' unclear or ungrammatical sentences and paste them in my comment section followed by my explanation of their mistakes.

\section{Discussion}

\subsection{Enhancing Motivation}

The results of the questionnaire, interviews, and observations indicated that the overall attitude of both the students and instructor towards the blog task was positive and satisfactory. In the interview, most students mentioned that the blog project was a novel and an entertaining experience for them compared with traditional writing assignments since its interactive nature helped motivate them to respond to each other. These findings echoed those of Vurdien (2013) and revealed that as digital natives, they felt more relaxed and motivated to complete an assignment online as they realized that their writings would be read by wider audiences. From several students' interview remarks and the instructor's observation log, the asynchronous nature of blogs benefited them in reading, writing, editing, and giving comments on their own postings as well as their peers'. Without being bounded by space and time, they could compose the text and look up words in online dictionaries. Moreover, participants strongly agreed on the efficiency and green nature of the blog task (item 14). Dippold (2009) posits that electronic feedback has the potential to accelerate the feedback process. More time must be invested in marking on paper and redistributing student work back and forth. Furthermore, the learners showed a positive attitude toward the authenticity of the blog instruction. Ward (2004) noted that blogs "are authentically communicative, process driven, peer reviewed, ...” (p. 3). Blogs can serve as a personal online diary or journal as well as an e-portfolio for the instructor to monitor and evaluate student work over a period of time (Yang, 2009).

\subsection{Training Analytical and Critical Skills}

By pointing out the unclear parts, grammatical and spelling errors in their peers' postings, students might develop analytical and critical skills. When students were leaving comment on their peers' blogs, they develop the feeling of empathy, which was profitable and fostered self-reflection. In turn, they would be more critical and 
analytical in their own writing. This is consistent with Vurdien (2013) who found that peer feedback through blogs "help students to reconsider their errors, which in turn may result in a positive impact on their learning process" (p. 137). Nonetheless, from the instructor's observation log, it was evident that a few students were not capable of providing constructive feedback because of their own low proficiency. However, they could still provide their reactions after reading their peers' postings. In such cases, these students were able to interact with their peers, but did not sufficiently meet the instructor's expectations of them. Although the current study provided peer feedback guide questions for the students before they left comments on their peers' postings, it is suggested that more specific guidelines with examples and training were needed to instruct the students, especially for those with low proficiency. The students would then know what kinds of errors they need to look for (fragments, run-on sentences, spelling) and would learn to be critical and analytical in their own writing.

\subsection{Learning from Peers}

From both the questionnaire (statement 8 with high degree of agreement at 4.34) and the interview, the students mentioned that they had learned from their peers by reading their peers' postings and they noted that reading the classmates' writing made them learn the organization of a writing (introduction, body and conclusion). Through blogs, students could easily access their peers' postings, which provided plentiful models as scaffolding for less proficient students. Drawing on Vygotsky's Zone of Proximal Development (ZPD), students can only achieve the area of ZPD through the assistance of experts, who can be the teachers or more knowledgeable learners. With the interactive nature of blogs, the students engaged in the interpersonal interaction with their peers, which empowered them to attain a higher level of performance (Saville-Troike, 2006). However, students felt that the tutor's feedback is more helpful than peer feedback in highlighting grammatical and spelling errors. Dippold (2009) similarly found that some students had no confidence in the quality of peer feedback as opposed to tutor feedback. Nevertheless, some students still said in the interview that although peer feedback was considered less valuable than the tutor's feedback, they still enjoyed reading and receiving it. If the feedback combined tutor and the peer comments, they found it especially useful. Evidence of this perception is found in statement 11 with a high degree of agreement (4.30).

Despite the benefit of peer and tutor feedback through blogs, providing feedback on blogs was not without problems. As the researcher found in the observation log, pointing out language errors on blogs took more time than marking errors on paper. Dippold (2009) also stated that from the viewpoints of both technology and teaching pedagogy, using blogs to highlight the linguistic or structural errors in detail must be reconsidered. Indeed, since blogs have become an alternative and creative tool for the teaching and learning of writing, writing teachers need to adopt this innovative thinking rather than traditional way of grading the students' writing paper and looking for grammatical errors in it. As Dippold (2009) suggested, "I believed that it might have been much more beneficial for the project to de-emphasize structures, and to stress the function-meaning aspects of language within the medium of blogs" (p. 34).

\section{Conclusion}

Blogging offers student learners a creative and communicative platform to present themselves in a meaningful and authentic way while interacting with each other. It also offers writing teachers an alternative for engaging students in writing activities and to promote student motivation and writing skills. This study offers insight into the perceptions of students toward incorporating blog tasks into writing classes as well as the helpfulness of peer feedback. Since the participants in the study are from three writing classes in the two universities in southern Taiwan, the results lack generalizability. However, the findings of this study are consistent with those of previous studies (Aljumah, 2012; Arslan \& Sahin-Kizil, 2010; Vurdien, 2013) with regard to the potential benefits of blogs in promoting writing skills. However, the results on peer feedback are mixed, as in previous studies. Although blogs might be more feasible than paper-based peer feedback, blog interfaces offer limited usefulness in highlighting mistakes when providing corrective feedback. Nevertheless, blogs permit other types of feedback such as exchanging ideas, negotiating for meaning, and responding questions. Despite their usefulness, this study suggests that blogs are better used to augment rather than replacing traditional writing assignments. Because the blog task is easily prepared, it can become a part of the regular writing class routine.

\subsection{Limitation and Further Research}

This study is limited by its small sample size and in engaging the participants in only one blog task, which may be insufficient for them to perceive the effectiveness of using blogs in promoting writing skills. Though this study has revealed voices and perceptions of the students and the teacher in writing classes, its findings are not generalizable because of its convenience sampling and small scale. Further research should explore whether the implementation of blogs can contribute to the development of students' writing skills, and whether peer feedback 
on blogs can trigger learners to edit their own writing.

\section{References}

Aljumah, F. H. (2012). Saudi learner perceptions and attitudes towards the use of blogs in teaching English writing courses for EFL majors at Qassim University. English Language Teaching, 5(1), 100-116. http://dx.doi.org/10.5539/elt.v5n1p100

Arnold, N., \& Ducate, L. (2006). Future foreign language teachers' social and cognitive collaboration in an online environment. Language Learning \& Technology, 10 (1), 42-66.

Arslan, R. S., \& Sahin-Kizil, A. (2010). How can the use of blog software facilitate the writing process of English language learners? Computer Assisted Language Learning, 23(3), 183-197. http://dx.doi.org/10.1080/09588221.2010.486575

Bakar, N. A., \& Ismail, K. (2009). Using blogs to encourage ESL students to write constructively in English. AJTLHE: ASEAN Journal of Teaching and Learning in Higher Education, 1(1), 45-57.

Chang, C. F. (2012). Peer review via three modes in an EFL writing course. Computers and Composition, 29, 63-78. http://dx.doi.org/10.1016/j.compcom.2012.01.001

Davis, J. N. (1997). Computer and L2 reading: Student performance, student attitudes. Foreign Language Annals, 30(1), 58-72. http://dx.doi.org/10.1111/j.1944-9720.1997.tb01317.x

Dippold, D. (2009). Peer feedback through blogs: Student and teacher perceptions in an advanced German class. ReCALL, 21(1), 18-36. http://dx.doi.org/10.1017/S095834400900010X

Hanrahan, S., \& Isaacs, G. (2001). Assessing self-and peer-assessment: The students' view. Higher Education Research \& Development, 20(1), 53-66. http://dx.doi.org/10.1080/07294360123776

Godwin-Jones, R. (2008). Emerging technologies web-writing 2.0: Enabling, documenting, and assessing writing online. Language Learning \& Technology, 12(2), 7-13.

Liu, N., \& Carless, D. (2006). Peer feedback: The learning element of peer assessment. Teaching in Higher Education, 11(3), 279-290. http://dx.doi.org/10.1080/13562510600680582

Min, H. T. (2006). The effects of trained peer review on EFL students' revisions types and writing quality. Journal of Second Language Writing, 15, 118-141. http://dx.doi.org/10.1016/j.jslw.2006.01.003

Nicol, D., \& Macfarlane-Dick, D. (2006). Formative assessment and self-regulated learning: A model and seven principles of good feedback practice. Studies in Higher Education, 31(2), 199-218. http://dx.doi.org/10.1080/03075070600572090

Richardson, W. (2005). Blogs, wikis, podcasts, and other powerful web tools for classrooms, Thousand Oaks, CA: Corwin Press.

Rollison, P. (2005). Using peer feedback in the ESL writing class. ELT Journal, 59(1), 23-30. http://dx.doi.org/10.1093/elt/cci003

Saville-Troike, M. (2006). Introducing second language acquisition. Cambridge: Cambridge University Press.

Sun, Y. C. (2009). Voice blog: An exploratory study of language learning. Language Learning \& Technology, 13(2), 88-103.

Sun, Y. C., \& Chang, Y. J. (2012). Blogging to learn: Becoming academic writers through collaborative dialogues. Language Learning \& Technology, 16(1), 43-61.

Trautmann, N. M. (2009). Interactive learning through web-mediated peer review of science reports. Educational Technology Research and Development, 57, 685-704. http://dx.doi.org/10.1007/s11423-007-9077-y

Vurdien, R. (2013). Enhancing writing skills through blogging in an advanced English as a Foreign language class in Spain. Computer Assisted Language Learning, 26(2), 126-143. http://dx.doi.org/10.1080/09588221.2011.639784

Vygotsky, L. S. (1978). Mind in society: The development of higher psychological processes. Cambridge, MA: Harvard University Press.

Ward, J. M. (2004). Blog assisted language learning (BALL): Push button publishing for the pupils. TEFL Web Journal, 3(1), 1-15.

Williams, J. B., \& Jacobs, J. (2004). Exploring the use of blogs as learning spaces in the higher education sector. Australasian Journal of Educational Technology, 20(2), 232-247. http://dx.doi.org/10.14742/ajet.1361 
Wu, W. V., Petit, E., \& Chen, C. (2015). EFL writing revision with blind expert and peer review using a CMC open forum. ReCALL, 28(1), 58-80. http://dx.doi.org/10.1080/09588221.2014.937442

Yang, S. H. (2009). Using blogs to enhance critical reflection and community of practice. Educational Technology \& Society, 12(2), 11-21.

\section{Appendix A}

\section{Peer Review Guide Questions}

1. What is the main idea or story in your classmate's blog posting?

2. What is your favorite part about your classmate's blog posting?

3. Which part of your classmate's blog posting is not clear to you?

4. Do you find any misspelled words? If yes, please point them out.

5. Do you find any ungrammatical sentences? If yes, please point them out.

6. Do you find any incorrect word usage? If yes, please point them out.

7. What questions do you have for the writer?

\section{Appendix B}

\section{Survey Questionnaire}

\begin{tabular}{|l|l|l|l|l|l|}
\hline & $\begin{array}{l}\text { Totally } \\
\text { agree }\end{array}$ & Agree & Neutral & Disagree & $\begin{array}{l}\text { Totally } \\
\text { disagree }\end{array}$ \\
\hline $\begin{array}{l}\text { 1. I think the writing course with the blog task incorporated } \\
\text { is more interesting than the traditional writing course. }\end{array}$ & $\square$ & $\square$ & $\square$ & $\square$ & $\square$ \\
\hline $\begin{array}{l}\text { 2. I would choose a writing course with the blog task } \\
\text { incorporated instead of a writing course without the blog } \\
\text { task incorporated. }\end{array}$ & $\square$ & $\square$ & $\square$ & $\square$ & $\square$ \\
\hline $\begin{array}{l}\text { 3. I feel writing blog assignments is easier and more } \\
\text { motivating than doing other writing assignments. }\end{array}$ & $\square$ & $\square$ & $\square$ & $\square$ & $\square$ \\
\hline $\begin{array}{l}\text { 4. I think the assignment in the blog task can facilitate my } \\
\text { writing fluency. }\end{array}$ & $\square$ & $\square$ & $\square$ & $\square$ & $\square$ \\
\hline $\begin{array}{l}\text { 5. I think completing blog assignments can be helpful in } \\
\text { promoting my writing skills. }\end{array}$ & $\square$ & $\square$ & $\square$ & $\square$ & $\square$ \\
\hline $\begin{array}{l}\text { 6. I feel the writing assignment in the blog task can be } \\
\text { helpful in practicing the English words I have learned. }\end{array}$ & $\square$ & $\square$ & $\square$ & $\square$ & $\square$ \\
\hline $\begin{array}{l}\text { 7. I think commenting on other classmates' blogs helps me } \\
\text { become more analytical and critical in my writing. }\end{array}$ & $\square$ & $\square$ & $\square$ & $\square$ & $\square$ \\
\hline $\begin{array}{l}\text { 8. I think reading other classmates' blogs is interesting and } \\
\text { enjoyable. }\end{array}$ & $\square$ & $\square$ & $\square$ & $\square$ & $\square$ \\
\hline $\begin{array}{l}\text { 9. Classmate's comments on my blog are helpful to me in } \\
\text { correcting the grammatical and spelling mistakes in my } \\
\text { own blog. }\end{array}$ & $\square$ & $\square$ & $\square$ & $\square$ & $\square$ \\
\hline $\begin{array}{l}\text { 10. Classmate's comments on my blog are helpful to me in } \\
\text { rewriting the unclear the expressions in my own blog. }\end{array}$ & $\square$ & $\square$ & $\square$ & $\square$ & $\square$ \\
\hline $\begin{array}{l}\text { 11. I enjoyed receiving peer feedback combined with tutor } \\
\text { feedback, which let me get feedback from different } \\
\text { perspectives (both the tutor and the peers) }\end{array}$ & $\square$ & $\square$ & $\square$ & $\square$ & $\square$ \\
\hline $\begin{array}{l}\text { 12. I think the teacher's comments are more helpful than } \\
\text { the peers' in correcting the grammatical and spelling }\end{array}$ & $\square$ & $\square$ & $\square$ & $\square$ & $\square$ \\
\hline
\end{tabular}




\begin{tabular}{|c|c|c|c|c|c|}
\hline mistakes on my blog. & & & & & \\
\hline $\begin{array}{l}\text { 13. I think the teacher's comments are more helpful than } \\
\text { peers' to me in rewriting the unclear expressions on my } \\
\text { blog. }\end{array}$ & $\square$ & $\square$ & $\square$ & $\square$ & $\square$ \\
\hline $\begin{array}{l}\text { 14. I think using blogs in writing classes are more efficient } \\
\text { and green. }\end{array}$ & $\square$ & $\square$ & $\square$ & $\square$ & $\square$ \\
\hline $\begin{array}{l}\text { 15. I think incorporating blogs into a writing course is an } \\
\text { authentic material and it is a way to integrate language } \\
\text { learning with real life, which is very meaningful. }\end{array}$ & $\square$ & $\square$ & $\square$ & $\square$ & $\square$ \\
\hline $\begin{array}{l}\text { 16. Reading classmates' blogs lets me get to know them } \\
\text { and their personalities more. }\end{array}$ & $\square$ & $\square$ & $\square$ & $\square$ & $\square$ \\
\hline
\end{tabular}

\section{Copyrights}

Copyright for this article is retained by the author(s), with first publication rights granted to the journal.

This is an open-access article distributed under the terms and conditions of the Creative Commons Attribution license (http://creativecommons.org/licenses/by/4.0/). 